\title{
A GEOGRAFIA OFICIAL PARA A EDUCAÇÃO DE JOVENS E ADULTOS NO BRASIL: AS INTENCIONALIDADES PARA A REPRODUÇÃO DO CONHECIMENTO GEOGRÁFICO
}

THE OFFICIAL GEOGRAPHY FOR THE EDUCATION OF YOUTH AND ADULTS IN BRAZIL: THE INTENTIONALITIES FOR THE REPRODUCTION OF GEOGRAPHICAL KNOWLEDGE

\section{LA GEOGRAFÍA OFICIAL PARA LA EDUCACIÓN DE JÓVENES $Y$ ADULTOS EN BRASIL: LAS INTENCIONALIDADES PARA LA REPRODUCCIÓN DEL CONOCIMIENTO GEOGRÁFICO}

\section{Rodrigo Coutinho Andrade}

Professor assistente do Departamento de Geografia do Instituto Multidisciplinar da Universidade Federal Rural do Rio de Janeiro (UFRRJ). Doutor em Educação pelo Programa de Pós-Graduação em Educação, Contextos Contemporâneos e Demandas Populares da Universidade Federal Rural do Rio de Janeiro. Membro do Grupo de Pesquisas sobre Trabalho Política e Sociedade da Universidade Federal Rural do Rio de Janeiro. Membro do Grupo de Trabalho de Ensino da Associação dos Geógrafos Brasileiros - seção Niterói.E-mail:rodrigoandrade@ufrri.br

\section{Resumo}

As políticas públicas para a Educação de Jovens e Adultos (EJA) se materializaram, no Brasil, após a ofensiva neoliberal, por meio da sincronia entre a gestão nos pressupostos do gerencialismo e a revisão das finalidades formativas sob a ótica do capital. Isto pode ser conferido pela ascensão e cristalização da pedagogia das competências, tendo em vista as novas morfologias do trabalho, assim como nas predileções para a cidadania de qualidade nova. Nesse sentido, no presente artigo, objetivamos identificar as transformações imputadas à EJA, ao longo dos últimos anos, no que tange às intencionalidades do processo de recomposição burguesa, verificando, nas políticas curriculares para o ensino de geografia, os impactos para a formação humana. Trata-se de uma pesquisa básica, de análise qualitativa, de caráter explicativo, que se insere na categoria de pesquisa de tipo bibliográfico-documental.

Palavras-chave: Educação de Jovens e Adultos (EJA), currículo, ensino de geografia, Brasil.

D D p.222-254, V.15, n.28, set./dez. 2019. 


\section{Abstract}

The public policies for Youth and Adult Education (EJA) materialized, in Brazil, after the neoliberal offensive by the synchronization between management in the assumptions of managerialism and the revision of formative purposes from the perspective of capital. This can be verified by the rise and crystallization of the pedagogy of competences in view of the new work morphologies, as well as the preferences for new quality citizenship. In this sense, the objective of this article is to identify the imputed transformations for EJA over the last years regarding the intentionalities of the bourgeois recomposition process, verifying in the curricular policies for the teaching of geography the impacts for the human formation. This is a basic research, qualitative analysis, explanatory character, which falls into the category of research of bibliographic-documentary type

Keywords: Youth and Adult Education (EJA), curriculum, geography teaching, Brazil.

\section{Resumen}

Las políticas públicas para la Educación de Jóvenes y Adultos (EJA) se materializaron, en Brasil, después de la ofensiva neoliberal mediante la sincronización entre la administración en los supuestos del gerencialismo y la revisión de los propósitos formativos desde la perspectiva del capital. Esto puede verificarse mediante el surgimiento y la cristalización de la pedagogía de competencias en vista de las nuevas morfologías de trabajo, así como las preferencias por una nueva ciudadanía de calidad. En este sentido, el objetivo de este artículo es identificar las transformaciones imputadas para la EJA en los últimos años con respecto a las intencionalidades del proceso de recomposición burguesa, verificando en las políticas curriculares para la enseñanza de la geografía los impactos para la formación humana. Se trata de una investigación básica, análisis cualitativo, de carácter explicativo, que entra en la categoría de investigación de tipo bibliográfico-documental.

Palabras-clave: Educación de Jóvenes y Adultos (EJA), plan de estúdios, enseñanza de geografia, Brasil. 


\section{Introdução}

A institucionalização da Educação de Jovens e Adultos (EJA), no Brasil, ocorreu de modo indissociável das intencionalidades formativas do bloco histórico (GRAMSCI, 2001; PORTELLI, 1978), contendo, em suas premissas, os determinantes orgânicos para a reprodução do capitalismo dependente associado ao padrão compósito de hegemonia burguesa (FERNANDES, 2006), simétricos, obviamente, aos fenômenos conjunturais em suas vicissitudes culturais, políticas, sociais e econômicas. Isto pode ser conferido na literatura dessa área, ${ }^{1}$ assim como na análise das políticas públicas para a EJA, no Brasil, que retratam a conjunção entre a frágil identidade desta modalidade de ensino e os anseios hegemônicos para a formação da classe trabalhadora.

Nos dias atuais, podemos conceber que a materialização das finalidades formativas da/ para a EJA ocorre no bojo das premissas da pedagogia da hegemonia (NEVES, 2005) e/ou da nova pedagogia política do capital (SOUZA, 2010). Isto por aglutinar tanto em seu conteúdo ético-político os ditames da sociabilidade burguesa e das novas morfologias do trabalho (ANTUNES, 2017), quanto na gestão educacional, sob as teses do gerencialismo e da Nova Gestão Pública (NGP), as predileções para a formação do homem de novo tipo (GRAMSCI, 2015), no atual contexto de recomposição burguesa ${ }^{2}$ e, consecutivamente, do reordenamento do controle sociometabólico derivado da crise estrutural do capital (MÉSZÁROS, 2011).

Por mais que tenham ocorrido avanços para a escolarização da população jovem, adulta e idosa demandante (por meio de dispositivos legais como o Artigo No 208 da Constituição Federal (BRASIL, 1988), que determina como direito público subjetivo o acesso ao ensino obrigatório (básico), de modo gratuito, sem distinção etária ou de qualquer tipo; a Lei de Diretrizes e Bases da Educação Nacional (LDB) (BRASIL, 1996), que reconhece a EJA como modalidade de ensino; e a reformulação do seu caráter por meio das Diretrizes Curriculares Nacionais (DCNEJA)), observamos a continuidade de seu ente precário, aligeirado e periférico. Tais premissas se sustentam por diversos fatores, cabendo aqui a ênfase para o financiamento, para a oferta da EJA ante à demanda bruta e relativa e para a(s) política(s) curricular(es).

\footnotetext{
Ver Haddad (2007), Haddad e Di Pierro (2006), Di Pierro (2005), Souza (2011), Paiva (1978; 2005), Santos (2011) e Fávero e Freitas (2011), entre outros.

2 O que denominamos de "recomposição burguesa" consiste na reconfiguração do regime de acumulação, por parte da classe burguesa, no sistema capitalista. Em sua peculiaridade, de acordo com o contexto sócio-histórico no qual se esgotam os elementos hegemônicos para a produção e a reprodução da hegemonia, institui programaticamente meios para "revolucionar incessantemente os instrumentos de produção, por conseguinte, as relações de produção e, com isso, todas as relações sociais" (MARX, ENGELS, 2015, p. 12). Esta característica ímpar, conforme o pensamento marxista, se materializa na capacidade de conservação-dissolução-criação ante movimentos de crise, e, consecutivamente, na restauração das bases de acumulação e da mediação do conflito de classe.
}

D

D Revista da Associação Nacional de Pós-graduação e Pesquisa em Geografia (Anpege).

D D

p.222-254, V.15, n.28, set./dez. 2019. 
Em relação ao financiamento, destacamos o ostracismo da EJA, provocado após a institucionalização do Fundo de Manutenção e Desenvolvimento do Ensino Fundamental e de Valorização do Magistério (FUNDEF), que estruturou esta modalidade de ensino como regular noturno, sob a responsabilidade dos sistemas subnacionais. Este fundo também provocou o incremento do ensino supletivo e da certificação dos estudos, ou a sua realização por meio dos programas federais, ao longo dos governos de Fernando Henrique Cardoso $^{3}$ e do Partido dos Trabalhadores (PT), reproduzindo o modelo histórico aligeirado e certificatório de escolarização. ${ }^{4}$

Após a aprovação e a efetivação do Fundo de Manutenção e Desenvolvimento da Educação Básica e de Valorização dos Profissionais da Educação (FUNDEB), verificamos certo otimismo pela inclusão da EJA no montante destinado à educação básica. No entanto, o fator de ponderação para essa modalidade de ensino $(0,8)$ ainda permanece como o menor para a pasta da Educação, ratificando o descompasso e a sua periferização no âmbito das políticas educacionais.

Tabela 1 - Comparação percentual das matrículas da EJA em relação aos recursos do FUNDEB.

Recursos da EJA no FUNDEB Matrículas da EJA x matrículas do FUNDEB

\begin{tabular}{lll}
\hline 2007 & $2,79 \%$ & $4,29 \%$ \\
\hline 2008 & $4,36 \%$ & $6,85 \%$ \\
\hline 2009 & $6,49 \%$ & $8,95 \%$ \\
\hline 2010 & $6,26 \%$ & $8,60 \%$ \\
\hline
\end{tabular}

Fonte: Extraído e adaptado de Carvalho (2014).

Acerca da relação da oferta da EJA ante a demanda bruta e relativa, sobreleva-se a seguinte assertiva de Castro (1993, p. 50): “Alfabetizar adultos é um suicídio econômico; um adulto que não sabe ler já se adaptou a esta situação". Isto se refletiu, e ainda se espraia, no processo de consolidação das medidas para a escolarização dos jovens, adultos e idosos, tomando-se como parâmetro tanto a alfabetização, quanto o término do último nível de ensino da educação básica ratificada pela LDB, ${ }^{5}$ como nos indicam os dados coletados e sistematizados pelo Censo Escolar do Instituto Nacional de Estudos e Pesquisas Educacionais Anísio Teixeira (INEP) e pelo Instituto Brasileiro de Geografia e Estatística (IBGE).

\footnotetext{
3 Destacamos o Programa Alfabetização Solidária (PAS), o Programa Nacional de Educação na Reforma Agrária (PRONERA) e o Plano Nacional de Formação do Trabalhador (PLANFOR).

4 A descontinuidade dos programas de escolarização e o caráter certificatório-aligeirado das medidas atuais podem ser conferidos, por exemplo, no salto do número de inscritos no Exame Nacional para Certificação de Competências de Jovens e Adultos (ENCCEJA), que contabilizou, em 2013, 128.581 candidatos, enquanto, no ano de 2018, foram 1.695.607.

5 Após a promulgação da LDB, a escolarização básica, de acordo com o Artigo No 4, compreende a educação infantil, o ensino fundamental e o ensino médio.
} 
Nos dias atuais, 6,8\% da população brasileira acima de 15 anos se encontram em condição de analfabetismo, totalizando 11.253.000 habitantes (IBGE, 2018). Podemos confirmar a tese de Castro (1993) pela significativa ampliação do quantitativo de analfabetos ao verificarmos a escolaridade-analfabetismo da população acima de 35 anos, cabendo destaque - negativo - para a população negra e parda, residente do/no campo e as classes menos abastadas.

Quando consideramos a conclusão dos níveis de ensino do segmento demográfico discriminado, podemos afirmar que a demanda pela EJA é expressiva, no Brasil, pois apenas 46,4\% da população acima de 15 anos concluíram a educação básica.

Tabela 2 - Escolaridade, por níveis de ensino, da população brasileira acima de 15 anos.

\begin{tabular}{l|c|c|c}
\multicolumn{1}{c|}{ Nível de ensino } & $\mathbf{2 0 1 6}$ & $\mathbf{2 0 1 7}$ & $\mathbf{2 0 1 8}$ \\
\hline Fundamental incompleto (ou curso equivalente) & 31,7 & 31,4 & 30,8 \\
\hline Fundamental completo (ou curso equivalente) & 10,4 & 9,7 & 9,2 \\
\hline Médio incompleto (ou curso equivalente) & 7,7 & 8,1 & 7,9 \\
\hline Médio completo (ou curso equivalente) & 26,6 & 27,2 & 27,4 \\
\hline Superior incompleto (ou curso equivalente) & 4,7 & 4,9 & 5,3 \\
\hline Superior completo & 12,6 & 12,9 & 13,7 \\
\hline
\end{tabular}

Fonte: $I B G E$ (2018).

Esses dados se agravam ao constatarmos o cenário de retração-estagnação da oferta da EJA no país, concomitante à intensificação da juvenilização desta modalidade de ensino. Desde o ano de 2008, de acordo com os dados do INEP, as matrículas e os espaços para a efetivação da EJA têm se retraído-estagnado paulatinamente, nos sistemas estaduais e municipais de ensino, considerando-se também os programas federais, com maior incidência no ensino fundamental - o que piora o cenário. Comparada aos demais níveis e modalidades, entre os anos de 2008 e 2017, a EJA foi o "segmento" educacional que apresentou o maior decréscimo do número de estabelecimentos. Enquanto a variação total abarcou a redução de 5,6\%, na educação básica, no Brasil, a EJA computou, no mesmo período (em uma década), o indicador negativo de 15,3\%.

Ao mesmo tempo, em contraposição aos ensinos fundamental, médio e superior, a EJA apresenta, de modo rotundo, o protagonismo-dependência da rede pública e do papel preponderante do Estado para a sua concreção, ao contabilizarmos 96\% das matrículas nesta esfera, no ano de 2017 (INEP, 2017), em contraposição à participação da rede privada

D

D D Revista da Associação Nacional de Pós-graduação e Pesquisa em Geografia (Anpege).

D D

p.222-254, V.15, n.28, set./dez. 2019. 
em outros setores. Isto reflete outra tendência da EJA, ao longo das últimas décadas, ou seja, a EJA tem, majoritariamente, um caráter público.

Gráfico 1 - Distribuição das matrículas de EJA de acordo com o caráter administrativo (1997-2017).

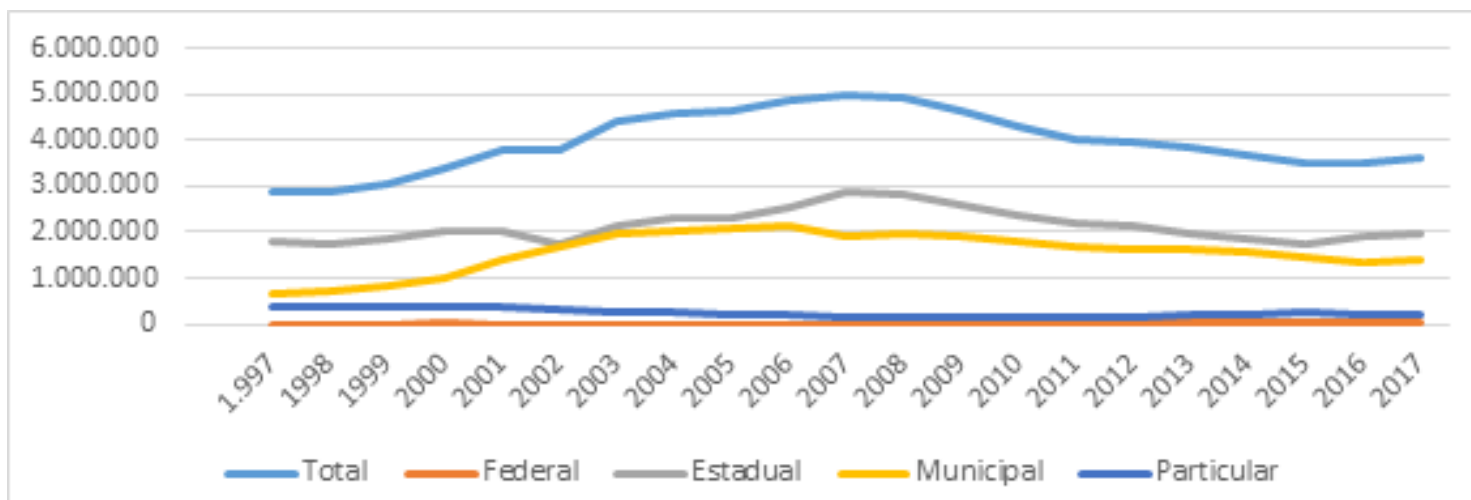

Fonte: INEP (2018).

Tabela 3 - Número de matrículas e estabelecimentos de EJA (2014-2018).

\begin{tabular}{ccc|c|c|c|c}
\hline & $\mathbf{2 0 1 4}$ & $\mathbf{2 0 1 5}$ & $\mathbf{2 0 1 6}$ & $\mathbf{2 0 1 7}$ & $\mathbf{2 0 1 8}$ \\
\hline Matrículas & 3.653 .530 & 3.491 .869 & 3.482 .174 & 3.598 .716 & 3.545 .988 \\
\hline Estabelecimentos & 36.761 & 34.589 & 31.964 & 32.262 & 31.184 \\
\hline
\end{tabular}

Fonte: INEP (2019).

\section{Gráfico 2 - Distribuição das matrículas da EJA de acordo com o segmento demográfico (2018).}

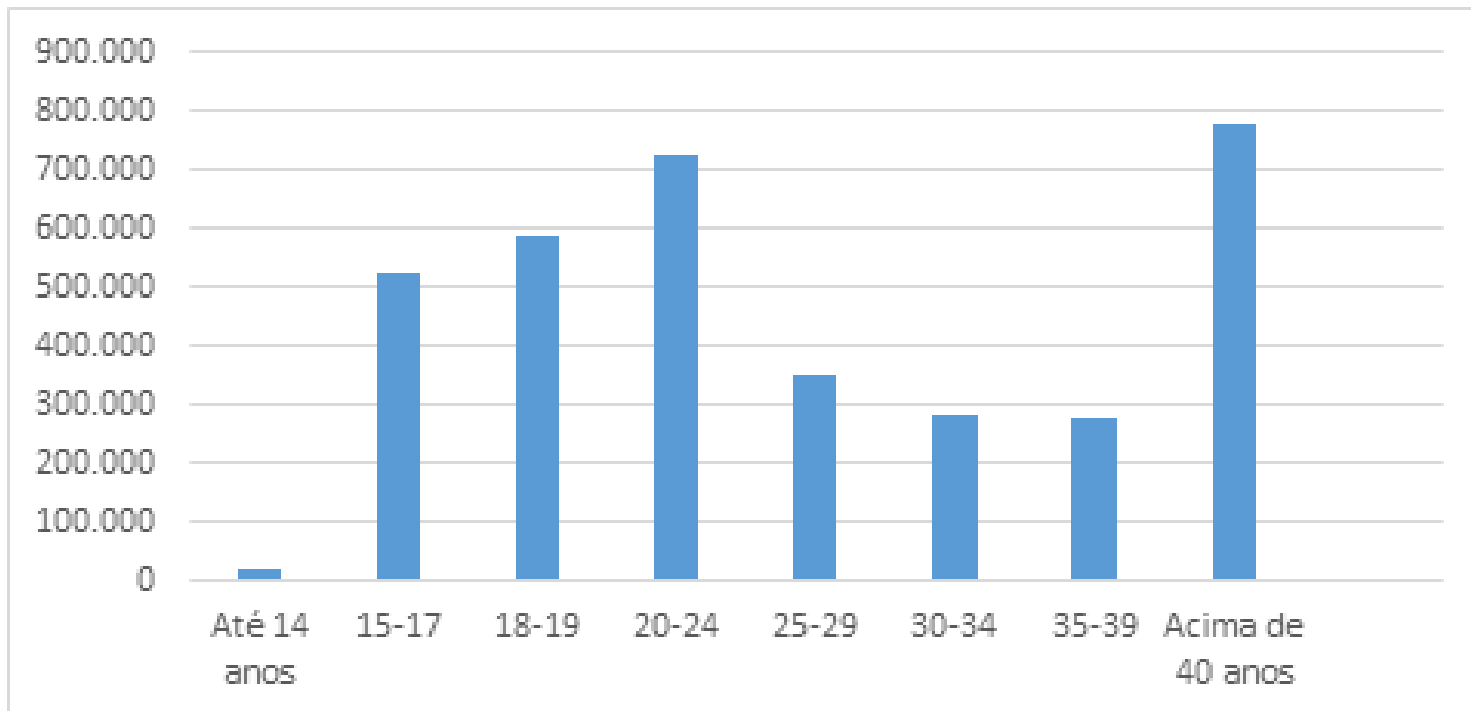

Fonte: INEP (2018). 
Por fim, sobre o que nos cabe uma maior proficuidade analítica, no presente estudo, destacamos as prescrições políticas curriculares para a EJA, no Brasil, após a consolidação da ofensiva neoliberal, considerando, principalmente, a Diretriz Curricular Nacional (DCN) para esta modalidade de ensino, que imputou a revisão das finalidades e dos objetivos, assim como a formulação das prescrições curriculares nos sistemas subnacionais. Tomaremos, inicialmente, a revisão da funcionalidade-finalidade da EJA, para, posteriormente, expor a sua operacionalização.

A principal preocupação dos formuladores da DCN residiu na supressão do caráter supletivo da EJA, por meio da contribuição de diferentes estudos, assim como na realização de audiências públicas com a participação constante do Sistema $S^{6}$ e de representantes da Organização das Nações Unidas para a Educação, a Ciência e a Cultura (UNESCO) (BRASIL, 2001, p. 112), objetivando a superação da histórica dualidade escolar no país, para além do escopo estrutural-material. Para tal, se redefinem os conceitos e funções da EJA, tendo como pressupostos os derivados da formação social brasileira em suas diferentes veredas, ressaltando, em sua teleologia, a "construção da cidadania" - entendida aqui como (de) limitada à sociabilidade burguesa.

Fazer a reparação dessa realidade, dívida inscrita em nossa história social e na vida de tantos indivíduos, é um imperativo e um dos fins da EJA, porque reconhece o advento desse princípio de igualdade para todos.

Desse modo, a função reparadora da EJA, no limite, significa não só a entrada no circuito dos direitos civis pela restauração de um direito negado - o direito a uma escola de qualidade -, mas também o reconhecimento daquela igualdade ontológica de todo e qualquer ser humano (BRASIL, 2001, p. 115).

Para além da função reparadora, se instituíram, para a EJA, as necessidades da escolarização básica para o "século que se avizinha e que está sendo chamado de 'o século do conhecimento"' (BRASIL, 2001, p. 116), sopesando a inclusão das competências para a vida cidadã e para o mundo do trabalho como um dos pilares da escola "democrática", e reproduzindo-se o mesmo "mantra" do Relatório Delors (DELORS, 1996) - os sintagmas do aprender a aprender - e das novas demandas sociais-laborais (DRUCKER, 1993). Tais argumentações se sustentaram nas teses acerca da relação entre a escolarização e a melhoria material-imaterial da reprodução social da classe trabalhadora, logrando, para o espaço escolar e seus sujeitos históricos, tal finalidade sem considerar as contradições ônticas e conjunturais

\footnotetext{
6 Este termo se refere ao conjunto de entidades forjadas pelo empresariado brasileiro, ao longo do século XX, com o objetivo de formar o homem de novo tipo (GRAMSCI, 2002), em todas as esferas - formação profissional, assistência social etc. -, indissociável de ações para o incremento nos diferentes setores da economia.
}

D D D Revista da Associação Nacional de Pós-graduação e Pesquisa em Geografia (Anpege).

D D p.222-254, V.15, n.28, set./dez. 2019. 
da relação capital-trabalho - como espelho da marca social da escola (GRAMSCI, 2001).7

Ao mesmo tempo, aloca-se, de modo impetuoso, o Estado como ente supraorgânico para a "reparação dessa dívida" (BRASIL, 2001, p. 117). Isto devido à sua potencialidade "instrumental" de inserir os sujeitos subalternos no mercado de trabalho, considerando o aspecto técnico da educação básica para o labor simples nos princípios da teoria do capital humano (SCHULTZ, 1978), e a eminência valorativa para a vida na sobrevalorização ético-política sob os princípios da cidadania ativa - o que categorizamos aqui como a reconfiguração dos mecanismos de mediação do conflito de classes (SOUZA, 2011). Seria esta a segunda função da EJA, de acordo com as DCN: a função equalizadora.

\begin{abstract}
As novas competências exigidas pelas transformações da base econômica do mundo contemporâneo, o usufruto de direitos próprios da cidadania, a importância de novos critérios de distinção e prestígio, a presença dos meios de comunicação assentados na microeletrônica requerem cada vez mais o acesso a saberes diversificados. A igualdade e a desigualdade continuam a ter relação imediata ou mediata com o trabalho. Mas seja para o trabalho, seja para a multiformidade de inserções sócio-político-culturais, aqueles que se virem privados do saber básico, dos conhecimentos aplicados e das atualizações requeridas podem se ver excluídos das antigas e das novas oportunidades do mercado de trabalho e vulneráveis a novas formas de desigualdades (BRASIL, 2001, p. 117).
\end{abstract}

Tais princípios se articulam à última função da EJA: a função qualificadora. Esta, de acordo com o referido documento (BRASIL, 2001, p. 118), não se coaduna consubstancialmente à qualificação, ou à educação profissional estrito senso, mas a implementação - nos distintos corpos curriculares - dos entes cognitivo-atitudinais para a formação humana visando ao trabalho sob os pressupostos da educação ao longo da vida sustentada. Observamos isto nos Parâmetros Curriculares Nacionais (PCN), assim como na atual Base Nacional Comum Curricular (BNCC) - prevista na LDB -, mesmo que não se dirija à EJA, na pedagogia das competências.

Essa tarefa de propiciar a todos a atualização de conhecimentos por toda a vida é a função permanente da EJA, que pode ser chamada de qualificadora. Mais do que uma função, ela é o próprio sentido da EJA, que tem como base o caráter incompleto do ser humano, cujo potencial de desenvolvimento e de adequação pode atualizar-se em quadros escolares ou não-escolares. Mais do que nunca, é um apelo para a educação permanente e para a criação de uma sociedade educada para o universalismo, a solidariedade, a igualdade e a diversidade. Como já dizia a Comissão Internacional sobre a educação para

Para Gramsci (2001, p. 49), esse modelo seria representado pela escola de tipo profissional, "preocupada em satisfazer interesses práticos imediatos", em contraposição à escola formativa, "imediatamente desinteressada", de cunho propedêutico. A escola, no capitalismo, teria a sua lógica, ou a sua "marca social", que é "dada pelo fato de que cada grupo social tem um tipo de escola próprio, destinado a perpetuar nestes estratos uma determinada função tradicional, dirigente ou instrumental" (GRAMSCI, 2001, p. 49). 
o século XXI, o chamado Relatório Jacques Delors para a UNESCO: Uma educação permanente, realmente dirigida às necessidades das sociedades modernas, não pode continuar a definir-se em relação a um período particular da vida - educação de adultos, por oposição à dos jovens, por exemplo - ou a uma finalidade demasiado circunscrita - a formação profissional, distinta da formação geral (BRASIL, 2001, p. 118).

Em outro momento, a DCN explicita que tal função se expressa no potencial humano para a contínua-necessária qualificação, destacando a adaptação dos estudantes para as transformações do mundo do trabalho - maleabilidade. Considerando-se a heterogeneidade do público da EJA e suas múltiplas experiências, valores e práticas culturais, a DCN para a EJA tem como principal finalidade a edificação de um arcabouço de princípios para a inclusão dos jovens, adultos e idosos no contexto escolar, obedecendo a horários específicos (geralmente, o noturno), o tratamento cognitivo diferenciado, a utilização de métodos ativos e a flexibilidade curricular que "deve significar um momento de aproveitamento das experiências diversas que esses alunos trazem consigo, como, por exemplo, os modos pelos quais eles trabalham seu tempo e seu cotidiano" (BRASIL, 2001, p. 158).

\begin{abstract}
A flexibilidade poderá atender a essa tipificação do tempo mediante módulos, combinações entre ensino presencial e não-presencial e uma sintonia com temas da vida cotidiana dos alunos, a fim de que possam tornar-se elementos geradores de um currículo pertinente. $O$ trabalho, seja pela experiência ou pela necessidade imediata de inserção profissional, merece especial destaque. A busca da alfabetização ou da complementação de estudos envolve um projeto mais amplo de cidadania que propicie inserção profissional e melhoria das condições de existência. Portanto, o tratamento dos conteúdos curriculares não pode ausentar-se dessa premissa fundamental, prévia e concomitante à presença em bancos escolares: a vivência do trabalho e a expectativa de melhoria de vida (BRASIL, 2001, p. 159).
\end{abstract}

Acerca da organização-efetivação das DCN para a EJA, predispostas na Resolução CNE/CEB N ${ }^{\circ}$ 1, de 5 de julho de 2000 (BRASIL, 2001), cabe destacar, inicialmente, a sua obrigatoriedade para as prescrições curriculares nos níveis de ensino fundamental e médio dos sistemas públicos, sendo opcional para as iniciativas autônomas. No entanto, queremos pontuar, no primeiro momento, que os Artigos No 3 e 4 (BRASIL, 2001) reiteram que as DCN do ensino fundamental e médio (regular) sejam estendidas para a EJA, de acordo com as Resoluções No 2 e 3 do CNE/CEB, de 1998, considerando orientações próprias dos sistemas de ensino estaduais e municipais, como o perfil e a faixa etária dos estudantes, sob as premissas da equidade, da diferença e da proporcionalidade.

Além disso, por meio da descentralização executiva, o Artigo № 6 reitera que "cabe a cada sistema de ensino definir a estrutura e a duração dos cursos da Educação de Jovens e Adultos, respeitadas as Diretrizes Curriculares Nacionais, a identidade desta modalidade

D

D Revista da Associação Nacional de Pós-graduação e Pesquisa em Geografia (Anpege).

D D

p.222-254, V.15, n.28, set./dez. 2019. 
de educação e o regime de colaboração entre os entes federativos" (BRASIL, 2001, p. 164). Como ressaltamos na introdução deste artigo, a reestruturação das EJA se materializou/ se materializa pelos marcos programáticos da NGP, ficando os municípios e os estados responsáveis pela adequação ou pela recontextualização do currículo, de acordo com as particularidades locais._Isto pode, em largo sentido, apontar para as questões territoriais e suas vicissitudes, mas explicita, como ente valorativo essencial, a refuncionalização da EJA, coadunada às prescrições da UNESCO - os determinantes hegemônicos.

No segundo momento, ressaltamos que as DCN para a EJA não suprimem os exames supletivos, de acordo com o Artigo No 9 (BRASIL, 2001, p. 164), mas estabelecem a sua regulamentação no mesmo propósito acima, incluindo também os cursos presenciais e à distância. Acrescemos que esta resolução reitera que as competências exigidas para a certificação dos estudos devem obedecer às DCN, para os níveis de ensino fundamental e médio "regular", dando sustentação futura para o ENCCEJA, criado no ano de 2002. Por fim, destacamos que as DCN para a EJA ratificam a limitação para o ingresso nesta modalidade de ensino, devido ao disposto pela $\mathrm{LDB}$, incluindo não só a permissão para a realização dos exames certificatórios, mas o seu ingresso na rotina escolar - delimitado para pessoas acima de 15 anos, no ensino fundamental, e de 18 anos, para o ensino médio.

Feitas, de modo panorâmico, as considerações iniciais sobre as transformações da EJA no país, com o objetivo de acamar o objeto de estudo, partiremos para o segundo momento, expondo as formas de ocupação-emprego dos trabalhadores brasileiros, na contemporaneidade._Neste momento, também vamos expor a síntese das novas morfologias do mundo do trabalho na mesma escala, para termos a dimensão avessa às assertivas formativas para o labor, na contemporaneidade. Cabe, então, questionar para qual trabalhomercado estamos formando. Ou se somos impulsionados pelas predileções hegemônicas para formar.

\section{A dinâmica da ocupação-labor-trabalho simples no Brasil: as novas morfologias do trabalho e os derivados para a formação humana}

De acordo com os dados do PNAD-IBGE relativos ao segundo semestre de 2019, a taxa de desocupação alcançou 12,4\%, alcançando a totalidade de 12,8 milhões de trabalhadores (IBGE, 2019). Mesmo contabilizando-se a ascensão da população ocupada em 1,6\%, em relação ao PNAD anterior, assim como o recuo da força de trabalho desocupada na ordem de $0,8 \%$, observamos a manutenção da subutilização da classe trabalhadora em 
aproximadamente $25 \%$ e dos desalentados em 4,4\%. Porém, a ascensão da ocupação requer atenção especial, diante da peculiaridade taxonômica quantitativa. Entre os ingressantes no mercado, o destaque cabe aos trabalhadores autônomos, incluindo os que prestam serviços mediados por aplicativos, ${ }^{8}$ que ascenderam em $1,6 \%$, dando prosseguimento à série histórica de superação do "trabalho com carteira assinada", e refletindo - não que este seja um determinante - a queda do rendimento médio desvelada pelo PNAD-IBGE.

Nesse sentido, objetivamos identificar como o atual quadro do mundo do trabalho, na materialidade concreta, exprime o recondicionamento da reprodução social e i-material da classe trabalhadora, e, consecutivamente, como isto se reflete na formação básica para jovens, adultos e idosos. Para tal, a partir de então, vamos apontar algumas considerações realizadas por estudiosos da Sociologia do Trabalho, tendo em vista a reformulação dos princípios pedagógico-curriculares para a educação, em tempos de desemprego.

O sintético quadro estatístico exprime parte significativa da reconfiguração tanto do mundo do trabalho, em suas novas morfologias no âmbito do regime de acumulação flexível (HARVEY, 1993), quanto a acentuação da subsunção da classe trabalhadora em sua relação com o capital - originada, principalmente, na ampliação do desemprego estrutural provocado pelos impactos do incremento técnico-tecnológico no setor produtivo e suas feições geográficas. Isto deu origem a um período composto de novos signos associados às formas pretéritas, que se orienta, principalmente, pela intensificação da exploração, ou sobre a responsabilização do indivíduo no período de flexibilização das relações trabalhistas e terceirização-terciarização do labor.

\begin{abstract}
Sua nova morfologia, isto é, sua forma de ser (para pensarmos em termos ontológicos), cujo elemento mais visível é seu desenho multifacetado, resultado das fortes mutações que abalaram o mundo produtivo do capital nas últimas décadas. Nova morfologia que abrange o operariado industrial e rural clássicos, até os assalariados de serviços, os novos contingentes de homens e mulheres terceirizados, subcontratados, temporários, que se ampliam. Nova morfologia que pode presenciar, simultaneamente, a retração do operariado industrial de base taylorano-fordista, e, por outro lado, a ampliação, segundo a lógica da flexibilidade toyotizada, dos novos modos de ser do proletariado, das trabalhadoras de telemarketing e call center, dos motoboys que morrem nas avenidas [...], dos digitalizadores que laboram (e se lesionam) nos bancos, dos assalariados do fast-food, dos trabalhadores dos hipermercados etc. Para não falar do trabalho escravo e semiescravo nos campos e no agronegócio (ANTUNES, 2011, p. 104, grifos do autor).
\end{abstract}

\footnotetext{
8 Ver:https://exame.abril.com.br/economia/apps-como-uber-e-ifood-sao-fonte-de-renda-de-quase-4-milhoes-de-pessoas/

9 Ver: https://g1.globo.com/economia/noticia/trabalho-sem-carteira-assinada-e-por-conta-propria-supera-pela1-vez-emprego-formal-em-2017-aponta-ibge.ghtml
}

D

D Revista da Associação Nacional de Pós-graduação e Pesquisa em Geografia (Anpege).

D D

p.222-254, V.15, n.28, set./dez. 2019. 
As novas formas de contratação, ancoradas na flexibilização como potencialidade para a ampliação do "emprego" sob a ótica do capital, materializam novos sentidos para a própria existência da classe trabalhadora por meio de sua insegurança, pois impõem progressivamente para a força de trabalho simples - principalmente -, mediante a pressão exercida pelo exército industrial de reserva, pelos salários achatados e pelas condições precárias de contrato (ou a inexistência deste).

Consecutivamente, assistimos a ascensão das novas formas legais que precarizam a totalidade social, combinadas à expansão dos flancos ilegais e informais. Isto se dá pela manifestação das novas formas de trabalho, ${ }^{10}$ na contemporaneidade, tendo como foco a adequação do trabalhador às demandas do capital - o incremento à adaptação tão reforçada pelas DCN para a EJA -, o que fez ascender, neste processo, novas categorizações, ${ }^{11}$ principalmente sobre a população jovem e feminina. Estes setores demográfico-sociológicos adentraram em um período de "recusa" ao trabalho no que tange à valoração fordista resultante da ofensiva ideológica do labor como forma de subsistência, criando uma população instável, sem qualquer reivindicação jurídica sobre as condições oferecidas (LINHART, 2007, p. 37).

O aumento de empregos precários, sobretudo dos jovens e das mulheres, é, antes de mais nada, o resultado de uma estratégia patronal que visa à maior flexibilidade possível na gestão da mão-de-obra, transformada em uma questão crucial em períodos de "crise" econômica. Mas podemos pensar que o crescimento das formas precárias de emprego (provisório, contratos por tempo determinados, estágios, tempo parcial), que tornam caduca uma parte da proteção social dos trabalhadores, encontrou apoio no "ambiente ideológico" criado por todos esses discursos e análise sobre a emergência de uma nova relação com o trabalho. Se, de fato, considerarmos que a maior parte dos jovens tem somente uma relação instrumental com o trabalho, ou seja, que o vê apenas como um simples meio de ganhar a vida, e que, portanto, sua socialização se faz em outros lugares, não há mais motivo para se chocar com a ampliação desses empregos temporários no mercado de trabalho (LINHART, 2007, p. 38).

\footnotetext{
${ }_{10}$ Vasapollo (2005, pp. 29-33, grifos do autor) destaca o trabalho interino, os trabalhos socialmente úteis, as bolsas de trabalho, os contratos temporários, o outsorcing, o staffleasing e o part-time, além da integração entre o trabalho e a aprendizagem.

11 Entre elas, destacamos os colaboradores, que "não têm, em comum, qualquer tipo específico de profissão, mas, ao contrário, realizam trabalhos os mais variados. A sua diversidade também é responsável pela disparidade de remuneração" (VASAPOLLO, 2005, p. 39). Em dados comparativos, no caso europeu, o autor citado ressalta que essa categoria aloca $41 \%$ dos jovens até 24 anos, que recebem, em média, três mil euros anuais. Sua volatilidade é brusca, assim como o seu rendimento, que, em muitos casos, fica restrito aos lucros da empresa, que os responsabiliza e os penaliza, caso estes lucros não ocorram.
} 
Não se modifica a relação capital-trabalho somente por meio da ascensão das novas formas de ocupação, mas a própria relação com o labor e sua significância na vida. O trabalho, que outrora poderia ser concebido como o espaço das reproduções sociais - e que não deixa de sê-lo, atualmente - se altera cada vez mais para a sua negação. O trabalho deixa de ordenar o tempo, se desideologiza, desestruturando também a esfera fora do trabalho, sendo o próprio sentido deste uma estratégia de captura da empresa flexível-toyotista para a construção do pertencimento a algo efêmero-mutável a qualquer instante.

Uma das conclusões plausíveis sobre a mutação do trabalho, no contexto do refino da reestruturação produtiva, é a de que a ofensiva do capital, no atual contexto sóciohistórico, tem como característica estruturante-endêmica o avanço e a aniquilação da própria identidade dos trabalhadores na conjuntura de flexibilização da mão-de-obra, de acentuação do desemprego estrutural e da redefinição dos valores existenciais (SENNETT, 2012, p. 63). A contradição que permeia o processo de enxugamento empresarial - e também dos espaços escolares -, assim como a especialização flexível do trabalhador e as demais formas de ocupação, está arraigada de estratégias para a sua desqualificação e desorganização. Estas estratégias têm base nos novos componentes ideológicos da/para a gestão do trabalho, nos Círculos de Controle de Qualidade (CCQs), na qualidade total e, principalmente, na gestão "participativa", que criam organicamente um novo tipo de proletário denominado agora como "colaborador", “empreendedor", "voluntário” etc.

Essa face pragmática consolidou o trabalho atípico, ao longo das últimas décadas, por se configurar em "formas ocultas de trabalho assalariado, subordinado, precarizado, instável, trabalho "autônomo" de última geração que mascara a dura realidade da redução do ciclo produtivo" (VASAPOLLO, 2005, p. 106). Sobre a autonomia, que, nos dias atuais, se transfigura material e imaterialmente, assim como a flexibilidade do tempo nos moldes do capital, emergem as novas formas de contratação e ocupação, como as medidas de zero hour contract, ${ }^{12}$ voucherização do trabalho-serviço e uberização.

\footnotetext{
${ }_{12}$ "Na Inglaterra, há a modalidade zero hour contract (o contrato de hora zero), que é o trabalho intermitente (proposta que consta na reforma trabalhista que tramita na Câmara dos Deputados). Médicos, advogados, atividades ligadas ao cuidado na saúde, eletricistas... As mais distintas categorias do chamado novo proletariado, especificamente o novo proletariado dos serviços. Esses trabalhadores são chamados e recebem apenas pelo trabalho realizado: não há contrato e não recebem direito nenhum. [...] Da mesma forma, podemos citar o exemplo italiano, onde há o trabalho a voucher. O trabalhador ou a trabalhadora realiza o trabalho, recebe um voucher e depois vai receber por aquelas horas. Isso abriu caminho para uma precarização enorme. O patronato paga por 20 horas de trabalho pelo sistema voucher, depois contrata por mais 20 horas. É o trabalho precário absoluto, que paga, inclusive, o valor mínimo por hora permitido na Europa" (ANTUNES, 2017a, p. 2).
}

D

D Revista da Associação Nacional de Pós-graduação e Pesquisa em Geografia (Anpege).

D D

p.222-254, V.15, n.28, set./dez. 2019. 
A uberização consolida a passagem do estatuto de trabalhador para o de um nanoempresário-de-si permanentemente disponível ao trabalho; retira-lhe garantias mínimas ao mesmo tempo em que mantém sua subordinação; ainda, se apropria, de modo administrado e produtivo, de uma perda de formas publicamente estabelecidas e reguladas do trabalho. [...] Podemos entender a uberização como um futuro possível para empresas em geral, que se tornam responsáveis por prover a infraestrutura para que seus "parceiros" executem seu trabalho; não é difícil imaginar que hospitais, universidades, empresas dos mais diversos ramos adotem esse modelo, utilizando-se do trabalho de seus "colaboradores just-in-time" de acordo com sua necessidade (ANTUNES, 2017a, p. 1).

A última característica aqui ressaltada para a exposição analítica da reestruturação produtiva reside naquilo que Alves (2011) conceitua como "captura da subjetividade"13 do trabalhador contemporâneo. Esta estratégia, muito bem propagada sob a ótica do capital pela empresa toyotista, se refere ao novo método de controle por meio da "ressocialização e aculturação pela conformação da subjetividade do trabalhador à lógica do capital" (ALVES, 2011, p. 77). Intrínseca à nova base técnica calcada na reconfiguração do "modelo das competências profissionais", esta estratégia se configura no

[...] Terreno ideológico a partir do qual se disseminam as noções estruturantes de flexibilidade, transferibilidade, polivalência e empregabilidade que irão determinar o uso, controle, formação e avaliação do desempenho da força de trabalho (ALVES, 2011, p. 76).

O salto desse estágio produtivo se deu mediante a capacidade da transformação das relações sociais de produção sob a égide da flexibilização, alcançando o chão de fábrica por meio do "envolvimento cooptado". Propagado sob o discurso da multiplicidade funcional do trabalho e da apologia à empregabilidade, a transformação produtiva, no bojo da racionalização da gestão do labor, impõe ao trabalhador novos imperativos, objetivando sua maleabilidade ao processo produtivo de modo conciliável à sua responsabilização competitiva para a reprodução material (ALVES, 2011; ANTUNES, 2005; 2009; SOUZA, 2012).

Sob a ideologia da gestão por competência focada no indivíduo, esse processo demarca a "reformulação da força de trabalho", combinando elementos para a redução salarial e a supressão do protagonismo do labor na geração de valor, gerando, consecutivamente, o esvaziamento da organização político-sindical (SOUZA, 2015). Tanto que as caraterísticas apontadas por Alves (2011, p. 108) alcançariam a necessária reciclagem geracional (juvenilização), no âmbito empresarial-corporativo, a formação-qualificação contínua (a

\footnotetext{
13 Esse autor expõe que o termo em si é uma metáfora para expor a "operação de produção de consentimento ou unidade orgânica entre pensamento e ação que não se desenvolve de modo perene, sem resistências e lutas cotidianas" (ALVES, 2011, p. 114, grifos do autor), mas que se materializa de modo dialético por articular instrumentos de controle e coerção, expandindo a manipulação para além do local de trabalho, visando, pelo método by panopticum, à sua reprodução nas instâncias sociorreprodutivas.
} 
educação ao longo da vida), o colaboracionismo (reengenharia ético-política e moral), o método kanban, a produtividade baseada em metas, e a introjeção em cada empregado do "olhar que perscruta o interior da alma humana" (ALVES, 2011, p. 115) ou, em outras palavras, a substituição do supervisor externo pelo supervisor interno. Sobre este processo, Alves considera que

[...] A reestruturação geracional dos coletivos de trabalho coloca, como um aspecto importante do dispositivo de "captura" da subjetividade do trabalho, o "esquecimento de experiências passadas", o apagar da memória de lutas e resistências e a construção ideopolítica de um novo mundo de colaboração e consentimento com os ideais empresariais. A nova geração de trabalhadores possui uma maior disposição de incorporar a linguagem empresarial em que o trabalhador deixa de ser "operário" e "empregado" e torna-se "colaborador" (ALVES, 2011, p. 109).

Como consequência, a reestruturação produtiva angaria uma nova linguagem e roupagem ideológico-política, intencionando a supressão da consciência de classe, indissociável da sua historicidade e dos resquícios solidários, instaurando um novo modo de controle social por meio da reformulação dos valores-fetiche e das utopias com base no consumo-competitividade-individualismo. Decorrente do mesmo processo, observamos a contínua fragilização-fragmentação da organização da classe trabalhadora, no bojo das reformas estruturais em curso, ${ }^{14}$ que se reproduzem por novos métodos de exploração do labor concomitantes ao desmonte das formas históricas de organização-resistência do proletariado (pela individualização das relações contratuais, pela desregulamentação das leis trabalhistas, pela terceirização, pela desprofissionalização, pelas novas formas precárias de trabalho etc.), somados às transformações do sindicalismo para as vertentes neocorporativas, ou caracterizados pela concertação social (SOUZA, 2002).

Sobre a ampliação da exploração, esta é descrita por Alves (2011, p. 64) como atributo qualitativo da nova morfologia da relação capital-trabalho por meio do processo de "desespecialização" dos sujeitos históricos, logrando ao proletariado o despojo de qualquer identidade - na ótica fordista-taylorista -, ou o significado concreto de sua prática no âmbito produtivo. A "flexibilidade" se torna, ao mesmo tempo, um conceito que determina a amplitude necessária à capacitação do trabalhador, desidentificado com uma função apenas, e, desta maneira, incorporado de uma polivalência vazia - a "certificação vazia”, para Kuenzer (2011). Além disso, a flexibilização incorpora a

\footnotetext{
${ }_{14}$ Como, por exemplo, a Reforma Trabalhista no Brasil. Esta, ratificada por meio da Lei No 13.467, de julho de 2017 (BRASIL, 2017), altera a Consolidação das Leis do Trabalho (CLT) para a contemplação das demandas estruturais, materializando a intensificação da precariedade do trabalho, por meio da regularização do trabalho intermitente, da sobreposição dos acordos coletivos à lei, da ausência de vínculo empregatício das empresas com os trabalhadores autônomos (impulsionando a terceirização do trabalho), de férias etc.
}

D

D D Revista da Associação Nacional de Pós-graduação e Pesquisa em Geografia (Anpege).

D D

p.222-254, V.15, n.28, set./dez. 2019. 
[...] Imprescindibilidade do "engajamento" moral-intelectual dos operários e empregados na produção do capital (o que implica a necessidade de "captura" da subjetividade do trabalho vivo pelos ditames da produção de mercadorias). O toyotismo mobiliza a subjetividade (ALVES, 2011, p. 46).

A própria desespecialização atribui um novo patamar de desintegração - vide "o ataque ao saber profissional dos operários qualificados, a fim de diminuir seu poder de produção e aumentar a intensidade do trabalho" (ANTUNES, 2011, p. 57). Ao mesmo tempo em que se intensifica o discurso para a qualificação, se aprofunda a sua atecnia, na realidade concreta. Portanto, acenar para um viés apenas é paradoxal no processo pedagógico. Além disso, afirmar a categorização do trabalhador com olhar sobre a formalidade empregatícia exclui a complexidade sobre a subproletarização que se intensifica, atualmente (ANTUNES, 2011).

$\mathrm{Na}$ contemporaneidade, o trabalho, de acordo com as demandas do capital, requer dialeticamente qualificações no bojo do processo de desidentificação funcional. Ao mesmo tempo em que se aprofundam as requisições para o aperfeiçoamento, não se distinguem, por trás deste manancial ideológico, as rupturas classistas no campo da formação e escolarização da classe trabalhadora, evidentes no refino da dualidade estrutural na/da (re)produção do conhecimento. Logo, a escola, sob os ditames da sociedade do conhecimento (DRUCKER, 1993), de modo estratégico, permanece no epicentro do debate sobre a economia capitalista, pois reproduz o papel crucial como aparelho privado de hegemonia - da reprodução da divisão social do trabalho -, assim como reproduz a sua funcionalidade, para além das premissas políticas para a reprodução social-material da vida na sociedade-sociabilidade burguesa.

Tendo como princípio o espírito da reforma gerencial do Estado e da ofensiva neoliberal, assim como seus pressupostos para o incremento da competitividade nacional no mercado internacional, promove-se, pelo mantra da qualificação, a reconfiguração do processo de inclusão social. Este processo, em si, tomando a dinâmica do mercado de trabalho, espelha a essência da inserção no mundo do labor na sociedade de classes, de modo subordinado e excludente, por incrementar "a destruição das subjetividades orgânicas aos regimes anteriores aliada à formação de novas subjetividades, que se ajustem à instabilidade, à flexibilização, à desqualificação" (KUENZER, 2011, p. 44).

Nesse sentido, compreendemos que a reconfiguração dos princípios ético-políticos da EJA, como conferido nas DCN, tem como finalidade objetiva a valorização do capital associada aos mecanismos de reconfiguração da mediação do conflito de classes. De um lado, servindo como instrumento de formação de um exército industrial de reserva de novo tipo - diferente daquele que alimentava a produção fordista. De outro, cristalizando-se como mecanismo para a conformação ético-política da classe trabalhadora em diálogo 
com os aparelhos privados de hegemonia, ratificando o compromisso para a promoção do desenvolvimento social e econômico fundado no consenso da classe dirigente (SOUZA, 2012, p. 30).

Considerando a inserção periférica da EJA nas políticas educacionais no país, ao longo da história, e sua permanência, nos dias atuais, em simetria às novas morfologias do trabalho, o projeto de qualificação dos estudantes matriculados nesta modalidade de ensino tende a fundir os princípios ético-políticos reificados, sob a ótica do capital, no atual contexto sócio-histórico. Reiteramos que o que está em jogo não é mais a preparação para o mercado de trabalho nos moldes fordistas, mas o apresto para a polivalência nos imperativos da flexibilização, que demanda "uma subjetividade que se ajuste à sazonalidade, à intensificação, à variabilidade das ocupações, à necessidade de adaptar-se a novas tarefas, enfim, uma força de trabalho com mobilidade e plasticidade" (KUENZER, 2011, p. 45), para que esta seja, quando necessária, incorporada à formalidade.

A competividade, tão reproduzida pelos intelectuais orgânicos do capital, é pedagogicamente transpassada para a classe trabalhadora, doravante entendida como capital (humano) por meio da pedagogia das competências. A competição em larga escala das nações se transmuta nos sujeitos sociais, que passam a enxergar o conhecimento como poupança, acúmulo, mas que é entendido pelo capital como descartável ante o incremento do trabalho morto, pois, como bem ressalta Kuenzer (2011, p. 47), "os arranjos são definidos pelo consumo da força de trabalho, e não a partir da qualificação".

O foco não é a qualificação em si, mas como ela se situa em dada cadeia produtiva, com o que ela se relativiza; a priori, não há como afirmar que certo trabalhador é ou não qualificado, uma vez que isto se define a partir de sua inclusão na cadeia; ou seja, a dimensão de relação social da qualificação se superlativiza na acumulação flexível, que avança na centralização do trabalho abstrato [...] O que determina a inclusão na cadeia não é a presença ou a ausência de qualificação, mas as demandas do processo produtivo que combinam diferentes necessidades de ocupação da força de trabalho a partir da tarefa necessária à realização da mercadoria (KUENZER, 2011, p. 47).

O que a autora supracitada reitera, acima, de modo convergente aos novos arranjos do mundo do trabalho no Brasil, após a década de 1990, é a sobrevalorização da adaptabilidade, principalmente por meio da captura da subjetividade (ALVES, 2011). Isto se reflete nas políticas públicas para a EJA, no que tange à formação-qualificação, tendo como "mantra" repetitivo, tanto nos documentos internacionais, quanto nas prescrições nacionais, a seguinte assertiva:

D

D Revista da Associação Nacional de Pós-graduação e Pesquisa em Geografia (Anpege).

D D

p.222-254, V.15, n.28, set./dez. 2019. 
A educação aumenta as habilidades, e pessoas com mais habilidades são mais empregáveis. Essa afirmação é verdadeira tanto na teoria quanto na prática. Evidências sólidas de todo o mundo mostram que, além de permitir que as pessoas desenvolvam novas habilidades, a educação e a aprendizagem levam a maiores salários, promovem satisfação no trabalho e incentivam o compromisso dos empregados com o trabalho. Como resultado, aumentam a produtividade e impulsionam o crescimento econômico (UNESCO, 2016, p. 87, grifo nosso).

Não queremos contradizer absolutamente o que está exposto acima, mas considerar como ocorre a produção-reprodução do conhecimento, na sociedade de classes, sob tais princípios, tendo ciência da progressiva simplificação do trabalho complexo e da reengenharia das qualificações para o ingresso no mercado de modo desigual, diferenciado e combinado, indissociável da acentuação do precariado (BRAGA, 2012). Para tanto, é irrefutável examinarmos a ascensão da pedagogia das competências e sua coexistência aos princípios do recrudescimento da teoria do capital humano. Sobre esta pedagogia, observamos, no primeiro momento, o incremento para a superação da concepção fordista, que se limita à "qualificação do emprego, do posto de trabalho" (HIRATA, 1997, p. 31), e para a reificação "da pessoa mais do que sobre o posto de trabalho" (HIRATA, 1997, p. 30), mediante a conjunção entre as qualidades éticas, morais e maleáveis dos sujeitos históricos (competências) e os meios para a "cooperação intersubjetiva", que nem sempre pode ser remunerada, vide as medidas do modelo zero hour contract.

Nos dias atuais, isso se espraia sobre a competência individual indissociável da noção de empregabilidade, como pode ser conferido nas prescrições-políticas curriculares. Para Hirata (1997, p. 33), essa competência individual cumpre duplo papel. O primeiro, seria a sua acepção positiva-idealista, como forma de migrar de trabalho para a obtenção de melhores rendimentos, ou a capacidade do indivíduo de obter "emprego" (sua capitalização no mercado, principalmente para a juventude). O segundo papel, mais importante para a presente análise por causa da sua sustentação no discurso sobre a crise da escola, assim como para a superação desta, está na função ideológica.

A noção de empregabilidade está associada a uma política de seleção da empresa e implica em transferir a responsabilidade da não-contratação (ou da demissão, no caso dos plans sociaux) ao trabalhador. Um trabalhador "não empregável" é um trabalhador não formado para o emprego, não competente etc. O acesso ou não ao emprego aparece como dependendo da estrita vontade individual de formação, quando se sabe que fatores de ordem macro e meso econômica contribuem decisivamente para essa situação individual (HIRATA, 1997, p. 33). 
Isto é, a responsabilização do trabalhador pela sua subsistência-trabalho se oblitera dos derivados estruturais. Por meio das competências (e da sua pedagogia) no contexto da crise do emprego, se desloca o conceito de qualificação ${ }^{15}$ como posto fixo no trabalho ou comprovado mediante o diploma para a potencialização abstrata dos sujeitos sociais.

\begin{abstract}
A lógica da competência se inscreve no movimento que se acirra nos anos 80 [...] de declínio das intervenções reguladoras do Estado no domínio econômico, modificando as formas de regulação entre oferta e demanda de emprego. Com a competência [...] a referência aos postos ideais (definidos no coração dos negócios coletivos e paritários) se rarefizeram em proveito das formas de adaptação à diversidade do concreto (RAMOS, 2001, p. 65).
\end{abstract}

A segunda observação se remete ao contexto de ampliação da subjugação da classe trabalhadora ante o capital devido às novas morfologias do trabalho, combinado à retração do Estado como mediador, fazendo ascender a função político-econômica das competências individuais. Esta função impetra a instabilidade positiva e negativa dos trabalhadores, assim como a sua individualização, sendo concebida e contabilizada pela produtividade como capital variável. O que muda, de fato, é a subjugação do conhecimento técnico pelo fazer - aprender a fazer -, que, somado à "valorização da implicação subjetiva no conhecimento, ela desloca a atenção para a atitude, para o comportamento e para os saberes tácitos dos trabalhadores" (RAMOS, 2001, p. 66, grifo nosso). Assim,

Por essa ótica, a emergência da noção de competência é fortemente associada a novas concepções do trabalho baseadas na flexibilidade e na reconversão permanente, em que se inscrevem atributos como autonomia, responsabilidade, capacidade de comunicação e polivalência. Neste sentido, o domínio do processo de trabalho faz apelo às qualificações tácitas, implícitas e não formalizadas por parte dos trabalhadores (RAMOS, 2001, p. 66).

A hegemonização do paradigma da competência se instaura na capacitação do trabalhador para responder às questões latentes, no cotidiano produtivo, de modo coletivo, por meio de suas próprias habilidades, assim como no direcionamento da inteligência para a ação-resolução de situações-problema - algo comum nas propostas curriculares. Seria esta a dimensão "experimental da qualificação" (RAMOS, 2001, p. 68). Os conhecimentos adquiridos são voltados completamente para o fazer, colocando o foco dos "objetivos de aprendizagem" nessas situações de modo material e imaterial.

\footnotetext{
15 "A lógica da qualificação desenvolveu o modelo de carreira, em que a trajetória profissional era enquadrada nos parâmetros de classificação, correspondentes aos conjuntos de postos reunidos por similaridade técnica. A progressão ao seio de uma carreira obedecia a regras que se aplicavam, particularmente nas grandes empresas, combinadas à antiguidade e à seleção apoiada sobre critérios objetivos. [...] Sob a égide da autonomia requerida pelos processos automatizados, as formas de gestão do trabalho fazem incidir sobre os próprios trabalhadores a responsabilidade por gerar condições de promoção" (RAMOS, 2001, p. 63), ou seja, trata-se de procedimentos endógenos à lógica gestão por competência.
}

D

D D Revista da Associação Nacional de Pós-graduação e Pesquisa em Geografia (Anpege).

D D

p.222-254, V.15, n.28, set./dez. 2019. 
A pedagogia das competências, que não se limita apenas ao fazer no trabalho, se materializa por meio da redefinição das relações sociais de produção na conjuntura de elevado desemprego e informalidade do labor. Como modus operandi tácito do capital, disseminado pelos aparelhos privados de hegemonia em tempos de transformação contínua das técnicas-tecnologias, se naturaliza a demanda-responsabilização do proletariado à sua adequação. Segundo Silva (2008, p. 66, grifo da autora), a competência se determina como "capacidade produtora de um indivíduo", se configurando não por uma série de "conhecimentos, habilidades e atitudes, mas da capacidade de combiná-los, integrá-los e utilizá-los de modo a atender ao que é requerido no contexto do trabalho". As competências se solidificam, na escola, como reflexo da atomização societária, por meio de uma metodologia cada vez mais individualizada-atomizada-competitiva, pois sua normalização-normatização é ratificada com base nos resultados e no desempenho quantificado da aprendizagem pelas avaliações externas, não dispensando as estratégias de motivação pessoal. Isto seria o apogeu da ética neoliberal para a reprodução social.

Por fim, reiteramos que esse tipo de formação, por meio da pedagogia das competências, logra, para a escola, um caráter altamente instrumental. Seria a reconfiguração da sua racionalidade fundamentada no mercado por meio da "dimensão subjetiva (mobilização de saberes e de recursos) e da dimensão social (ação, desempenho e performance)" (SILVA, 2008 , p. 89). Isto impacta a totalidade dos sistemas de ensino, principalmente o currículo e as práticas curriculares-pedagógicas reguladas pelo Estado-avaliador, por meio das quais se consolida a redefinição da política do conhecimento sustentada no pragmatismo como forma, inclusive, de superação do fracasso escolar.

Decorrente da necessária conformação (sob a ótica do capital) dos homens e mulheres no contexto de elevada "desempregabilidade", se centraliza a responsabilização individual pela condição material dos trabalhadores, induzindo sua formação à potencialidade do saber-fazer. Nesse sentido, a pedagogia das competências cimenta, na escola, os pressupostos sistêmicos da administração privada e do comportamento humano, resgatando princípios behavioristas (SILVA, 2008). Sua normatização reside no mesmo campo do gerencialismo por seguir critérios de avaliação e de responsabilização dos indivíduos - competição administrada.

Tal face administrativa incorpora os objetivos do regime de acumulação flexível, assim como os pressupostos neoliberais, por meio das medidas de accountability, que, além de proporcionar o controle exógeno, materializa a autorregulação de modo individualizado. 
Daí o caráter "flexível" da força de trabalho: importa menos a qualificação prévia do que a adaptabilidade, que inclui tanto as competências anteriormente desenvolvidas, cognitivas, práticas ou comportamentais, quanto a competência para aprender e para submeter-se ao novo, o que supõe subjetividades disciplinadas que lidem adequadamente com a dinamicidade, a instabilidade, a fluidez. O discurso da necessidade de elevação dos níveis de conhecimento e da capacidade de trabalhar intelectualmente, quando adequadamente analisado a partir da lógica da acumulação flexível, mostra seu caráter concreto: a necessidade de ter disponível para consumo, nas cadeias produtivas, força de trabalho com qualificações desiguais e diferenciadas que, combinadas em células, equipes, ou mesmo linhas, atendendo a diferentes formas de contratação, subcontratação e outros acordos precários, assegurem os níveis desejados de produtividade, por meio de processos de extração de mais-valia que combinam as dimensões relativa e absoluta (KUENZER, 2017, p. 341).

Para isso, são elaborados "planos superestruturais", no corpo do Estado Ampliado, sendo a escola o espaço de cimentação do conformismo, no primeiro momento, passando, posteriormente, para a coletivização do tipo social hegemônico (GRAMSCI, 2001, p. 39). Seria esta sua arquitetura a que materializa a concepção de mundo da classe dirigente que orientará a prática política dos subalternos no sistema capitalista - os mecanismos de mediação do conflito de classes. Categorizada por Neves (2005) como a "nova pedagogia da hegemonia", a primeira marca desta tese advém da repolitização ${ }^{16}$ da política no cerne da mediação de Terceira Via, ${ }^{17}$ para a consolidação de um novo senso comum, com base no "associativismo colaboracionista; ou mesmo quando desenvolve valores que impulsionam soluções individualistas ou grupistas na resolução de questões relativas ao trabalho e à vida" (MARTINS, NEVES, 2010, p. 36).

A nova pedagogia da hegemonia é promovida para a alteração da natureza da formação do trabalho simples e complexo, na contemporaneidade, tendo como finalidade a instauração de uma nova cultura cívica. Disseminado pelos principais aparelhos privados de hegemonia no país (NEVES, 2005, pp. 99-110), e consolidando práticas em prol do "novo espírito voluntário" por meio do redirecionamento da luta política (SOUZA, 2002), a cidadania de novo tipo se baliza em três iniciativas indissociáveis. A primeira delas tem como finalidade

\footnotetext{
${ }^{16}$ Esta repolitização, nos dias atuais, se cimenta sobre a ideologia da responsabilidade social, carregada de termos e da ideologia empresarial, para a formação de um novo perfil de trabalhador categorizado como "empreendedor" e "colaborador" (MARTINS, NEVES, 2015).

17 Uma das principais características do bloco histórico que se forma a partir da nova pedagogia da hegemonia, envolvendo a formação de novas teorias, a formação de novos intelectuais orgânicos e a difusão pedagógica dos novos consensos, é o realinhamento ideológico de teóricos e de forças políticas nas relações sociais e de poder. Este realinhamento sugere que, com a "crise do marxismo", a "morte do socialismo" e a "insuficiência da perspectiva neoliberal", o futuro da política estaria localizado num plano que vai além das formas clássicas de "esquerda" e “direita” (MARTINS, NEVES, 2010, p. 25).
} 
[...] A viabilização do retorno ou da permanência de um conjunto significativo da população ao nível mais primitivo das relações de forças, aquele estreitamente ligado à estrutura objetiva, no qual os agrupamentos sociais organizam-se conforme sua função e posição na produção, sem uma maior consciência de seus papéis econômico e político-social. Nesse primeiro sentido, a nova pedagogia da hegemonia propõe-se a estimular um tipo de participação que, fortemente relacionada ao conceito gramsciano de catarse, tenta incentivar movimentos caracterizados por soluções individuais (NEVES, 2005, p. 35).

A segunda iniciativa se refere, literalmente, ao desmantelamento da organização da classe trabalhadora, sendo refuncionalizada para a construção de uma nova sociabilidade no contexto de diluição da consciência de classe e fragmentação dos trabalhadores.

A nova pedagogia da hegemonia atua no sentido de restringir o nível de
consciência política coletiva dos organismos da classe trabalhadora que
ainda atuam no nível ético-político para o nível econômico corporativo. Mais
precisamente, a nova pedagogia da hegemonia estimula a pequena política
em detrimento da grande política, propiciando, contraditoriamente, à classe
trabalhadora a realização da grande política de conservação. Vale lembrar
ainda, conforme a orientação gramsciana, que os movimentos em torno da
pequena política traduz-se-iam, exemplarmente, tanto no plano mundial
quanto regional, em ações como projetos de auto-ajuda, estímulo a um conceito
de cidadania restrita, ênfase em ações destinadas à valorização de demandas
e espaços comunitários e locais, dentre tantos outros (NEVES, 2005, p. 37).

Tal estratagema se enquadra na análise de Neves (2005) acerca da consolidação da nova pedagogia da hegemonia, por cristalizar a educação para o desemprego, principalmente pela repolitização da classe trabalhadora e pela apologia da empregabilidade, além de consolidar elementos indissociáveis da nova cultura cívica.

Essa educação vem sendo propagada por diferentes meios, mas a escola continua sendo o espaço privilegiado para a conformação ético-política do "novo homem", de acordo com os princípios hegemônicos. O "novo homem", nessa visão de mundo, deve: sentir-se responsável individualmente pela amenização de uma parte da miséria do planeta e pela preservação do meio ambiente; estar preparado para doar uma parcela do seu tempo livre para atividades voluntárias nessa direção; exigir do Estado em senso estrito transparência e comprometimento com as questões sociais, mas não deve jamais questionar a essência do capitalismo. À escola, portanto, é transmitida a tarefa de ensinar as futuras gerações a exercer uma cidadania de "qualidade nova", a partir da qual o espírito de competitividade seja desenvolvido em paralelo ao espírito de solidariedade, por intermédio do abandono da perspectiva de classe e da execução de tarefas de caráter tópico na amenização da miséria em nível local (NEVES, 2005, p. 211).

A cidadania "de qualidade nova" é intrínseca ao novo ordenamento social mundial, que intenciona a revisão das condutas individuais, corporativas e dos governos (NEVES, MARTINS, 2015, p. 35). Ao mesmo tempo, seria resultante da sociedade do conhecimento, 
tomando como sustentação a noção de colaboração social na limitação da participação política por via das estratégias da "democracia consentida" (NEVES, MARTINS, 2015, p. 35). ${ }^{18}$ Sua materialização se intensifica ao longo dos anos 1990, após a Conferência de Jomtien, que deu origem ao programa Educação para Todos, da UNESCO, movimento que originou o processo de expansão da escolarização sob os princípios neoliberais, com foco na reformulação valorativa da cidadania, nos direitos de aprendizagem, na responsabilidade social, no desenvolvimento sustentável e na geração de renda.

Será esta a face do "capitalismo humanizado" que, por meio da construção do consenso sobre valores no bojo da dialética mercado-justiça social, promoveria a reconstruçãoprivatização - endógena - dos sistemas de ensino. Por meio do discurso acerca da crise da escola e de sua ineficiência na obtenção dos resultados e da coesão social, a classe empresarial ampliou sua entrada nas escolas para difundir o seu ideário de vida (NEVES, MARTINS, 2015), tendo como base o Relatório Delors (UNESCO, 2000) para a consolidação dos quatro pilares da educação: aprender a conhecer, aprender a fazer, aprender a viver juntos e aprender a ser. $\mathrm{O}$ que a geografia tem a ver com isso?

\section{A geografia oficial para a EJA e a necessidade de sua superação}

Entendemos como geografia oficial os derivados das políticas curriculares para esta ciência no cotidiano escolar, que, na atual conjuntura, se esmera nos debates acerca da BNCC, e que pode, em certo sentido, equivaler à geografia dos professores (LACOSTE, 1988). No entanto, em relação à EJA, cabe uma ressalva, antes de examinarmos as correlações entre a atual prescrição curricular e a geografia escolar: esta advém do distanciamento da EJA nos currículos dos cursos de licenciatura, de modo geral. Segundo Soares (2011) e Machado (2008), a formação de docentes para atuação na EJA era, até a década de 1980, uma prerrogativa da "Escola Normal" para a habilitação apenas nas séries iniciais do ensino fundamental. Após essa década, mediante os esforços dos intelectuais dessa área, se iniciou um movimento de habilitação profissional com ênfase em EJA, resultando, no ano de 2006, em 27 cursos, entre os 1.698 Institutos de Ensino Superior (IES) então existentes.

\footnotetext{
18 Esse processo foi aprofundado por meio do incentivo à criação de "canais de participação da sociedade civil, sob os argumentos da cidadania reflexiva, com o objetivo de ampliar o consenso da sociedade em torno do projeto de sociabilidade por meio de políticas que combinaram o caráter focalizado com respostas efetivas a demandas sociais concretas" (SOUZA, MELO, BONATTO, 2015, p. 86). Estes novos canais foram efetivados, principalmente, nos governos após o mandato de Fernando Henrique Cardoso, que, por meio das teses de ampliação do controle social, ratificaram as parcerias com a sociedade civil e o empresariado para consultoria e execução, fazendo com que se ampliasse a participação da sociedade para o autocuidado.
}

D

D Devista da Associação Nacional de Pós-graduação e Pesquisa em Geografia (Anpege).

D D

p.222-254, V.15, n.28, set./dez. 2019. 
Em breve pesquisa realizada nos fluxogramas de cursos, para exemplificação desta assertiva, constatamos que não existe uma disciplina destinada à EJA, nos cursos de licenciatura das universidades e faculdades públicas de Geografia, no estado do Rio de Janeiro, nem como eletiva-optativa. Há apenas a sua inclusão específica nas disciplinas de Estágio Supervisionado ou de Prática de Ensino, consecutiva das DCN para a formação docente. Podemos afirmar que não existe uma disciplina para o tratamento direto específico de $9 \%$ dos matriculados nas diferentes redes de ensino do país e de quase a metade dos estudantes, quando se compara ao ensino médio (INEP, 2017). Acrescemos a este fato a análise de Ventura:

Considerando as DCN que organizam os cursos de algumas áreas do conhecimento, é possível constatar que a EJA não é mencionada ou, quando muito, é citada de maneira vaga, sendo indicado que, para questões referentes às licenciaturas, seja consultado e considerado outro documento, externo às proposições dos cursos e comum a todos (VENTURA, 2013, p. 75).

Como reiteramos anteriormente, isso se reflete, na atualidade, pela rasa inclusão da EJA na formação inicial, sendo esta contemplada pontualmente na capacitação nas escalas subnacionais ou de modo específico, para o exercício em programas (SOARES, 2008, p. 85). Em todo caso, não existe uma especificidade ou um concurso específico exigido para se lecionar na EJA, o que relega ao ostracismo esta modalidade de ensino que ainda é reproduzida no corpo das políticas públicas nos mesmos moldes da educação básica. Ou seja, a ideia de que basta apenas "boa vontade" ou voluntarismo profissional para a atuação na EJA ratifica a fragilidade de sua identidade, afetando as especificidades metodológicas para a relação ensino-aprendizagem desta modalidade.

Os professores que trabalham na educação de jovens e adultos, em sua quase totalidade, não estão preparados para o campo específico de sua atuação. Em geral, são professores leigos ou recrutados no próprio corpo docente do ensino regular. Note-se que na área específica de formação de professores, tanto em nível médio quanto em nível superior, não se tem encontrado preocupação com o campo específico da educação de jovens e adultos; devem-se também considerar as precárias condições de profissionalização e de remuneração destes docentes (HADDAD, DI PIERRO, 1994, p. 16).

Retomando o debate, inicialmente, pontuamos o afastamento da EJA das políticas curriculares, na contemporaneidade, o que não nos coloca como favoráveis à BNCC. Ao que tudo indica, tomando como exemplos tanto os institutos sociais, ${ }^{19}$ quanto os intelectuais orgânicos do capital, ${ }^{20}$ ocorrerá a mesma iniciativa impetrada pelas DCN para a EJA, tal como quando os sistemas subnacionais de ensino ficaram sob esta responsabilidade,

\footnotetext{
${ }_{19}$ Ver: https://institutoayrtonsenna.org.br/pt-br/BNCC.html

${ }^{20}$ Ver: https://www.revistaeducacao.com.br/falta-de-diretrizes-para-eja-na-base-preocupa-educadores/
} 
orientados pelas apriorísticas norteadoras. ${ }^{21}$ De acordo com Maria Helena Guimarães, ${ }^{22}$ então secretária executiva do Ministério da Educação, em 2017, a não inclusão da EJA na BNCC partiu de duas premissas: a primeira foi a não estigmatização do público da EJA pela exceção à educação regular; a segunda, a mais comum entre os defensores da BNCC, foi a negação desta como currículo. Ao mesmo tempo em que as escolas e os profissionais da educação se tornam os principais responsáveis pela elaboração do currículo - o que concebemos como um fato positivo -, ocorre dialeticamente a ausência de formação específica para tal, como apontado na ressalva, considerando de imediato a negação da particularidade dessa modalidade de ensino.

Entretanto, nos dias atuais, o que se materializa é a correspondência dos princípios norteadores da BNCC para a EJA ancorados na pedagogia das competências. Ao analisarmos a atual prescrição curricular, identificamos nova roupagem em sua definição, abarcando as aprendizagens essenciais e os direitos de aprendizagem coadunados à sétima meta do atual Plano Nacional de Educação (PNE), que objetiva o aprendizado na idade certa - é inoportuno tratar sobre isto em relação à EJA. Como objetivo, a atual prescrição curricular se afirma como

[...] Referência nacional para a formulação dos currículos dos sistemas e das redes escolares dos Estados, do Distrito Federal e dos Municípios e das propostas pedagógicas das instituições escolares, a BNCC integra a política nacional da Educação Básica e vai contribuir para o alinhamento de outras políticas e ações, em âmbitos federal, estadual e municipal, referentes à formação de professores, à avaliação, à elaboração de conteúdos educacionais e aos critérios para a oferta de infraestrutura adequada para o pleno desenvolvimento da educação (BRASIL, 2018, p. 8).

Nesse ponto, ocorre uma assimetria aparente-latente pela disparidade entre a autonomia docente para a construção do currículo e as iniciativas para a superação da fragmentação das políticas educacionais. Seria o paradoxo entre a assertiva da BNCC como um não currículo e a sua afirmação para uma política educacional integradora sob as premissas do direito à aprendizagem. Por isso, nos ancoramos na hipótese de que a BNCC terá o papel dos Parâmetros Curriculares Nacionais (PCN), que se transformaram num aporte para os conteúdos escolares por meio de um rol de competências e habilidades, como bem assenta sua estrutura explicitada em dez competências gerais

\footnotetext{
${ }^{21}$ Afirmação realizada pela intelectual orgânica do capital Guiomar Namo de Mello, em reportagem realizada pela Revista Educação, que se reitera na introdução da BNCC (BRASIL, 2018, p. 7).

D

D Devista da Associação Nacional de Pós-graduação e Pesquisa em Geografia (Anpege).

D $D$

p.222-254, V.15, n.28, set./dez. 2019. 
[...] definida como a mobilização de conhecimentos (conceitos e procedimentos), habilidades (práticas, cognitivas e socioemocionais), atitudes e valores para resolver demandas complexas da vida cotidiana, do pleno exercício da cidadania e do mundo do trabalho (BRASIL, 2018, p. 8).

Sobre a definição acima, já concluímos, anteriormente, suas feições em relação ao mundo do trabalho, suas novas morfologias e os impactos para a formação humana, que conferem à educação a responsabilização-atomização dos sujeitos sociais. Acerca do exercício da cidadania, trataremos posteriormente. Em relação às competências gerais, se destacam a valorização cultural, os aspectos que tangem a identidade, as novas tecnologias, o protagonismo pessoal na vida coletiva "alinhadas ao exercício da cidadania" (BRASIL, 2018, p. 9), o cuidado com a saúde física e emocional (competência socioemocional) e outros valores que se coadunam ao "cidadão de novo tipo".

Isso pode ser conferido nas competências para as ciências humanas, que partem do princípio do "desenvolvimento da cognição in situ" (BRASIL, 2018, p. 348), indissociável da contextualização espaço-tempo. O instrumental para este desenvolvimento se baseia nos princípios da diferença, tomando-se como prisma a escala do lugar, e objetivando politicamente a formação ética sob o senso de responsabilidade, o respeito ao ambiente e à coletividade, o fortalecimento de valores sociais e o protagonismo voltado ao bem comum (BRASIL, 2018, p. 352) - ou seja, a coadunação da cidadania aos anseios das teses liberais sobre a educação (TONET, 2005).

Em relação à instrumentalização da categoria cidadania, na BNCC para a Geografia, na educação básica, não encontramos elementos destoantes do que já fora apontado, mas, sim, a sua imbricação com os entes paradigmáticos contemporâneos para a reprodução do conhecimento geográfico na escola, ancorados principalmente na construção de conceitos para a sustentação do "raciocínio geográfico".

Essa é a grande contribuição da Geografia aos alunos da Educação Básica: desenvolver o pensamento espacial, estimulando o raciocínio geográfico para representar e interpretar o mundo em permanente transformação e relacionando componentes da sociedade e da natureza. Para tanto, é necessário assegurar a apropriação de conceitos para o domínio do conhecimento fatual (com destaque para os acontecimentos que podem ser observados e localizados no tempo e no espaço) e para o exercício da cidadania (BRASIL, 2018, p. 365).

A não diferenciação desse princípio na totalidade do texto da BNCC para a Geografia se exprime na finalidade do ensino de geografia na educação básica, que aponta primazias à EJA, reiterando a cidadania como exercício indissociável da vida cotidiana e do lugar, tendo como finalidade as intencionalidades no âmago da convivência e o bem comum. 
Em todas essas unidades, destacam-se aspectos relacionados ao exercício da cidadania e à aplicação de conhecimentos da Geografia diante de situações e problemas da vida cotidiana, tais como: estabelecer regras de convivência na escola e na comunidade; discutir propostas de ampliação de espaços públicos; e propor ações de intervenção na realidade, tudo visando à melhoria da coletividade e do bem comum (BRASIL, 2018, p. 363).

Tais finalidades correspondem às premissas apontadas, assim como às derivações contemporâneas da categoria cidadania e sua instrumentalização. Ao mesmo tempo, além de constituir, no sujeito-indivíduo, as consignas para sua reprodução social e material no contexto de crise orgânica do capital, destituindo os determinantes do bloco histórico das causalidades, não aprofunda, em nenhum momento, os significados do "bem comum", deixando de modo implícito a reprodução dos ditames da sociabilidade contemporânea burguesa. Isto se aprofunda quando verificamos a reprodução das suas intencionalidades no ensino médio.

\footnotetext{
Para atender às necessidades de formação geral, indispensáveis ao exercício da cidadania e à inserção no mundo do trabalho, e responder à diversidade de expectativas dos jovens quanto à sua formação, a escola que acolhe as juventudes tem de estar comprometida com a educação integral dos estudantes e com a construção de seu projeto de vida (BRASIL, 2018, p. 464, grifos nossos).
}

Acerca da estruturação da geografia na BNCC, em relação ao arcabouço teóricometodológico e à organização das competências, observamos certo ecletismo, como já apontado por Rocha (2010), em sua análise sobre os PCN. Para a consolidação de sua finalidade como componente curricular, se mesclam diferentes conceitos geográficos para a "construção da identidade". Assentados nos derivados epistêmicos do espaço vivido, com base nos pressupostos da fenomenologia e do socioconstrutivismo, para a reprodução das vicissitudes do raciocínio geográfico, calcados na diferença e na identidade (MOREIRA, 1999), se reificam como geografia oficial (ROCHA, 2010, p. 23). No entanto, o último (raciocínio geográfico), tomado como principal fundamentação para a ciência geográfica na escola, se espraia no método da "geografia tradicional" (BRASIL, 2018, p. 361), o que deixa claro a insuficiência metódica do paradigma fenomenológico na/para a geografia escolar, que se agrava ao capturar a análise de Moreira (1999, pp. 41-53) sem considerar o seu conteúdo marxista para o desvelo da reafirmação da diferença, do espaço.

Se, no passado, o PCN de Geografia se exercitou para lograr ao ostracismo as contribuições do marxismo por meio de argumentações simplórias (ROCHA, 2010), nesta prescrição curricular, ocorre de modo sincrético, mantendo a mesma premissa e (com as ressalvas do termo) oportunista, pois não vislumbra, em momento nenhum, a identidade por meio da "diferença como conteúdo concreto. Não diferença como mediação

D

D Revista da Associação Nacional de Pós-graduação e Pesquisa em Geografia (Anpege).

D D

p.222-254, V.15, n.28, set./dez. 2019. 
da identidade, pura categoria do método da representação" (MOREIRA, 1999, p. 54), mas a diferença que polimorfiza os indivíduos, imputando a "morte do sujeito universal", do sujeito como classe, como também frisa Rocha (2010, p. 24).

Se, anteriormente, os problemas para o ensino da geografia - sob a ótica de Moreira (1999) - se enveredavam para a sua fragmentação, assim como para a instrumentalização da "geografia dos professores", como bem apontam Lacoste (1988) e Moreira (1987), atualmente, ela se reorganiza como uma ciência aplicada nos espaços escolares para a reprodução ético-valorativa de cunho neoliberal. Por meio do exame do componente curricular geográfico, podemos constatar as mesmas premissas (não explícitas) dos PCN apontadas por Rocha (2010, p. 23) na execração das contribuições da geografia tradicional e do marxismo, apontando também sua insuficiência para a compreensão da realidade. Nesse sentido, ainda observamos como "clara a intenção do Estado em oficializar uma geografia de fundamentação fenomenológica e construtivista nas salas de aula, como podemos concluir se analisarmos as prescrições feitas para esta disciplina no contexto da política curricular oficial em implementação no Brasil” (ROCHA, 2010, p. 24).

Esse paradigma tem como primazia, nos pressupostos observados acerca da geografia que se quer que se ensine, a abordagem com foco no indivíduo e no comportamento por meio das representações e imaginários, imputando a subjetividade - fragmentada - categorizada pelo espaço vivido. Além de reproduzir uma revisão-obliteração do objeto da geografia (o espaço geográfico em sua materialidade concreta), aloca o indivíduo-percepção como conhecimento em seus aspectos exógenos e psicológicos, retraindo a essência da coisa em si em sua totalidade categórica e ontológica da humanidade - o trabalho (SANTOS, 1978).

\begin{abstract}
Há por parte da geografia da percepção, assim como pela do comportamento, uma preocupação com a elaboração de um enfoque globalizador e subjetivo da realidade. Para estas abordagens, o espaço, em decorrência de seu caráter abstrato, deixa de ser a referência central dos estudos geográficos, sendo substituído pelo espaço vivido, construto social resultante da percepção e das experiências dos indivíduos.
\end{abstract}

Desta forma, pode-se afirmar que, para cada homem e cada mulher, existe uma imagem diferente do espaço, apreendida a partir do que eles e elas percebem do mundo que os(as) rodeia, afinal, se a consciência é sempre a "consciência de alguma coisa" e o objeto é sempre o objeto-para-o sujeito, o espaço só existe para a consciência do homem ou da mulher (ROCHA, 2010, p. 25).

Traçando o paralelo entre os PCN e a BNCC, podemos ressaltar que a essência da geografia oficial ainda mantém a primazia do "psicologismo desvairado" (ROCHA, 2010) transverso pelas competências. Rocha (2010, p. 25) se perguntava sobre os objetivos e 
os porquês de o Estado prescrever, para o currículo, esta geografia calcada em tais bases ante as reformas educacionais em curso, sob o epíteto neoliberal. Concebemos que, para além de sua conclusão sobre o banimento da categoria classe e dos adendos do "fim da história”, da revisão adaptada da geografia da percepção e da geografia humanística, acrescida de uma ética para o consumo, coexistem os princípios das novas morfologias do trabalho pela impetração oculta (e, por vezes, explícita) das teses acerca da flexibilização, da individualização, da captura da subjetividade, da empregabilidade e da adaptabilidade. Isto não só por se ancorar nas bases do paradigma da competência, mas por extirpar, como método para a relação ensino-aprendizagem para a EJA, as contradições da materialidade concreta em sua essência; as relações sociais de produção.

\section{Considerações finais}

Considerando as limitações de um artigo, apontamos, mesmo que de modo panorâmico, as bases sócio-históricas para a reprodução do conhecimento escolar, na contemporaneidade, tomando as mutações impetradas pelo processo de recomposição burguesa. Esta recomposição alcança a totalidade dos sistemas de ensino, tanto na gestão das políticas educacionais, quanto nas verticalidades para a relação ensino-aprendizagem - não querendo, com isso, afirmar que os professores reproduzem mimeticamente o seu conteúdo.

Por meio da categoria cidadania, identificamos ancoradouros para a formação do "homem de novo tipo", mediante a cimentação da pedagogia das competências e de toda reformulação das políticas curriculares sob as premissas da pedagogia da hegemonia, que tem como finalidade a construção dos mecanismos para a mediação do conflito de classes e a obtenção da maleabilidade dos trabalhadores às novas morfologias do trabalho.

Para a identificação da nova engenharia no bojo da tradição seletiva curricular, expusemos as premissas da BNCC para a formação humana e suas refrações para a geografia escolar voltada à EJA. Diante do examinado, concluímos que o paradigma hegemônico atual, no campo do ensino de geografia - devendo ser ressaltadas as suas relevantes contribuições para o avanço desta ciência -, se imbrica, de modo fortuito, para a contemplação das finalidades formativas sob a ótica do capital, contendo, em seu vértice, os elementos epistemológicos e o conteúdo da mediação política nos anseios da Terceira Via. Ademais, isto se reitera pela individualização do processo ensino-aprendizagem, assim como a sua predisposição para o subjetivismo amparado no conceito de espaço vivido, se conflagrando progressivamente como a geografia oficial do Estado.

D

D Revista da Associação Nacional de Pós-graduação e Pesquisa em Geografia (Anpege).

D D

p.222-254, V.15, n.28, set./dez. 2019. 
Nesse sentido, mesmo a EJA tendo um caráter periférico na totalidade das políticas públicas para a educação e sendo lograda ao ostracismo nas políticas curriculares (vide a reprodução das premissas da BNCC), atentamos para o seu refino discursivo e pragmático, na atualidade, por meio das competências socioemocionais em tempos de intensificação da precariedade do trabalho, e, ao mesmo tempo, com as intencionalidades intergeracionais (vide a juvenilização desta modalidade de ensino). Se constatamos que existem diversos problemas na oferta e na estruturação da EJA, assim como na sua gelatinosa identidade, reiteramos que o projeto político-pedagógico, neste contexto sócio-histórico, se baliza nas mediações para a (con)formação de jovens, adultos e idosos às contradições da sociedade de classes por meio dos princípios de Jomtien - Relatório Delors -, assim como nas medidas para a mediação do conflito de classes (vide a potencialidade da juventude para ocasionar distúrbios à ordem societária burguesa).

Isso se confirma na estrutura ética, política e moral em que a geografia se institui na BNCC, e que também deriva as unidades temáticas, os objetos de conhecimento e as habilidades, traçando os conteúdos nas escalas subnacionais. Em contraposição, defendemos que o ensino de geografia abarque as contradições da contemporaneidade, tendo como base o trabalho e a sua primordial concepção para a produção do espaço geográfico, sendo este pensado por meio de conceitos norteadores para as práticas-práxis espaciais sob os princípios da totalidade e suas mediações e contradições.

\section{Referências}

1. ALVES, Giovanni. Trabalho e subjetividade: o espírito do toyotismo na era do capitalismo. São Paulo: Boitempo, 2011.

2. ANTUNES, Ricardo. O caracol e sua concha: ensaios sobre a nova morfologia do trabalho. São Paulo: Boitempo, 2005.

3. __ As configurações do trabalho na sociedade capitalista. In: Revista Katálysis, v. 12, n. 2, 2009.

4 . . O privilégio da servidão: o novo proletariado de serviço na era digital. São Paulo: Boitempo Editorial, 2017.

5 . . Entrevista. São Paulo: Brasil de Fato. 19 de setembro de 2016. Disponível em: $<$ https://www.brasildefato.com.br/2016/09/19/temer-e-capaz-de-regredir-lei-rabalhistaa-epoca-da-escravidao-diz-ricardo-antunes/>. Acesso em: 10 de junho de 2017. 
6. BRASIL. Constituição da República Federativa do Brasil. Brasília, DF: Senado Federal, 1988. . Ministério da Educação e do Desporto. Conselho Nacional de Educação. Câmara de Educação Básica. Diretrizes Curriculares Nacionais. Brasília: MEC: 2001.

8. Presidência da República. Lei No 13.467, de julho de 2017. Altera a Consolidação das Leis do Trabalho (CLT), aprovada pelo Decreto-Lei No 5.452, de $1^{\circ}$ de maio de 1943 , e as Leis No 6.019, de 3 de janeiro de 1974, 8.036, de 11 de maio de 1990, e 8.212, de 24 de julho de 1991, a fim de adequar a legislação às novas relações de trabalho. Brasília, 2017. Disponível em: <http://www.planalto.gov.br/ccivil_03/_Ato2015-2018/2017/Lei/ L13467.htm>. Acesso em: 02 de agosto de 2019.

9. Ministério da Educação. Base Nacional Comum Curricular. Brasília: MEC, 2018.

10. CARVALHO, Marcelo Pagliosa. O financiamento da EJA no Brasil: repercussões iniciais do FUNDEB. In: Revista Brasileira de Política e Administração da Educação, v. 30, n. 3, 2014.

11. CASTRO, Claudio Moura e. A receita dos educadores. Revista Veja. São Paulo, p. 50, 23 de jun. de 1993. Disponível em <https://acervo.veja.abril.com.br/index.html\#/ edition $/ 33$ 249? page $=50 \&$ section $=1>$. Acesso em: 23 de outubro de 2016 .

12. DELORS, Jacques et al. Educação: um tesouro a descobrir - Relatório da Unesco da Comissão Internacional sobre Educação para o Século XXI. Brasília: Unesco, 1996.

13. DI PIERRO, Maria Clara. Notas sobre a redefinição da identidade e das políticas públicas de educação de jovens e adultos no Brasil. In: Educação \& Sociedade, v. 26, n. 92, 2005.

14. DRUCKER, Peter. A sociedade pós-capitalista. São Paulo: Pioneira, 1993.

15. FERNANDES, Florestan. A revolução burguesa no Brasil: ensaio de interpretação sociológica. Rio de Janeiro: Globo, 2006.

16. GRAMSCI, Antonio. Cadernos do cárcere. Volume 3: Maquiavel. Notas sobre o Estado e a política. Rio de Janeiro: Civilização Brasileira, 2000.

17. Cadernos do cárcere. Volume 2: Os intelectuais. O princípio educativo. Jornalismo. Rio de Janeiro: Civilização Brasileira, 2001.

18. Cadernos do cárcere. Volume 4: Temas de cultura. Ação católica. Americanismo e fordismo. $5^{\text {a }}$ ed., Rio de Janeiro: Civilização Brasileira, 2015.

19. HIRATA, Helena. Os mundos do trabalho. In: CASALI, Alípio et al. Empregabilidade e educação: novos caminhos no mundo do trabalho. São Paulo: EDUC, 1997. 
20. Instituto Brasileiro de Geografia e Estatística. Pesquisa Nacional de Amostra por Domicílio, 2019. Rio de Janeiro: IBGE, 2014. Disponível em: <https://ww2.ibge.gov. $\mathrm{br} /$ home /estatistica/pesquisas/pesquisa_resultados.php?idpesquisa $=40>$. Acesso em: 20 de agosto de 2019.

21. INEP. Censo Escolar da Educação Básica, 2018. Brasília, DF: INEP, 2018. Disponível em: <http://www.inep.gov.br>. Acesso em 6 de julho de 2019.

22. KUENZER, Acacia Zeneida. Pedagogia da fábrica: as relações de produção e a educação do trabalhador. In: Em Aberto, v. 4, n. 28, 2011.

23. . Trabalho e escola: a flexibilização do ensino médio no contexto do regime de acumulação flexível. In: Educação \& Sociedade, v. 38, n. 139, 2017.

24. LACOSTE, Yves. A geografia - isso serve, em primeiro lugar, para fazer a guerra. São Paulo: Papirus, 1988.

25. LINHART, Danièle. A desmedida do capital. São Paulo: Boitempo, 2007.

26. MACHADO, Maria Margarida. Formação de professores para EJA: uma perspectiva de mudança. In: Retratos da Escola, v. 2, n. 2/3, 2012.

27. MARTINS, André Silva; NEVES, Lúcia Maria Wanderley. A direita para o social e esquerda para o capital: intelectuais da nova pedagogia da hegemonia no Brasil. São Paulo: Xamã, 2010.

28. . Educação básica: tragédia anunciada? São Paulo: Xamã, 2015.

29. MARX, Karl; ENGELS, Friedrich. Manifesto comunista. Boitempo Editorial, 2015.

30. MÉSZÁROS, Îstvan. A crise estrutural do capital. São Paulo: Boitempo, 2011.

31. MOREIRA, Ruy. O discurso do avesso: para a crítica da geografia que se ensina. Rio de Janeiro: Dois Pontos, 1987.

32. . A diferença e a geografia: o ardil da identidade e a representação da diferença na geografia. In: GEOgraphia, v. 1, n. 1, 2009.

33. NEVES, Lúcia Maria Wanderley (org.). A nova pedagogia da hegemonia: estratégias do capital para educar o consenso. São Paulo: Xamã, 2005.

34. PORTELLI, Hugues. Gramsci e o bloco histórico. Rio de Janeiro: Paz e Terra, 1977.

35. RAMOS, Marise Nogueira. A pedagogia das competências: autonomia ou adaptação. São Paulo: Cortez, 2001. 
36. ROCHA, Genylton Odilon Rêgo da. O ensino de geografia no Brasil: as prescrições oficiais em tempos neoliberais. In: Revista Contrapontos, v. 10, n. 1, 2010.

37. SANTOS, Enio Serra dos. O mundo do trabalho na geografia a ser ensinada na educação de jovens e adultos. In: Revista Brasileira de Educação em Geografia, v. 1, n. 1, 2011.

38. SANTOS, Milton. Por uma Geografia Nova. São Paulo: Hucitec, 1978.

39. SENNETT, Richard. A corrosão do caráter: as consequências pessoais do trabalho no novo capitalismo. Rio de Janeiro: Record, 2012.

40. SILVA, Monica Ribeiro da. Currículo e competências: a formação administrada. São Paulo: Cortez, 2008.

41. SOARES, Leôncio José Gomes. Do direito à educação à formação do educador. In: SOARES, Leôncio; GIOVANETTI, Maria Amélia Gomes de Castro; GOMES, Nilma Lino (orgs.). Diálogos na educação de jovens e adultos. Belo Horizonte: Autêntica Editora, 2011.

42. SOUZA, José dos Santos. Trabalho, educação e sindicalismo: anos 90. Campinas, São Paulo: Autores Associados, 2002.

43. A EJA no contexto das políticas públicas de inclusão de jovens no mercado de trabalho. In: SOUZA, José dos Santos; SALES, Sandra Regina (orgs.). Educação de Jovens e Adultos: políticas e práticas educativas. Rio de Janeiro: Nau Editora; EDUR, 2011. 44. O sindicalismo brasileiro e a qualificação do trabalhador. Londrina: Praxis; Bauru: Canal 6, 2015.

45. TONET, Ivo. Educar para a cidadania ou para a liberdade? In: Perspectiva, v. 23, n. 2,2005

46. UNESCO. Relatório Global sobre Aprendizagem e Educação de Adultos. Brasília: UNESCO, MEC, 2016.

47. VASAPOLLO, Luciano. O trabalho atípico e a precariedade. São Paulo: Expressão Popular, 2005.

48. VENTURA, Jaqueline Pereira. A EJA e os desafios da formação docente nas licenciaturas. In: Revista da FAEEBA - Educação e Contemporaneidade, v. 21, n. 37, 2013. 